\title{
Professional Reflection and Self-reflection in the Educational Work of Secondary School Teachers
}

\author{
Michal Novocký
}

\begin{abstract}
This paper will discuss the issue of teachers' reflection and self-reflection within the scope of teaching and extracurricular educational activities. Every teacher should realise the significance of the elements of reflection and self-reflection as they may help to improve their educational work. Only those teachers who evaluate and revise their decisions on a regular basis and rectify individual educational elements have an excellent starting point to achieve progressive changes in their work. Teachers with routine educational methods should be replaced by reflective professionals aware of the need of their continual improvement, therefore they should permanently contemplate about themselves, the students and external and internal teaching conditions. The research focuses on determining the frequency of teachers' reflection of educational elements and the frequency of their professional self-reflection from the point of view of the career level and the type of education. The tool used for the collection of data was a questionnaire of our own design, mostly based on response scales.
\end{abstract}

Key words: professional reflection, professional self-reflection, education, secondary school. 


\section{Introduction}

Teaching is a demanding profession. It requires continuous study and constant selfreflection, revaluation and revision of one's own teaching theory. Teachers need to be reflective and never become fully satisfied with their work but constantly look for ways to improve and avoid routine approach towards education. It will be greatly appreciated by students, and it may manifest in improved school results, activity or behaviour because the influence the teacher has on them is also of crucial importance. Self-reflective teachers make use of several reflective and self-reflective methods and sources in his/ her work; is aware of what he/she needs to learn and is able to describe and analyse the relationship with other people within the school environment.

\section{Professional self-reflection as an important part of educational work of secondary school teacher}

The educational process is complex, and dynamic and it should be implemented by every teacher in a deliberate, systematic and methodical way in order to optimally fulfil specified educational targets. These targets must be met by means of relevant didactic and educational methods, as well as other educational means. Thus, not only getting to know students but also the knowledge of one's own capabilities and their further improvement should be a platform for every teacher.

The educational process must be dialectical and it is the teacher who should have the greatest interest in ensuring that individual elements are balanced and in harmony. The teacher's potentiality and possibilities are important conditions of education. It shouldnot be forgotten that it is these conditions that are rudimentary determinant responsible for the effectiveness of the educational process.

What is important for the teacher is to be satisfied with his/her own educational work and for the student to feel motivated to study further and to change his/her behaviour and way of acting. To achieve that, the teacher must employ professional self-reflection.

"Professional self-reflection means that the teacher employs retrospection to focus on his/her teaching methods and actions within the classroom, thoughts, attitudes, emotions and activities that also apply to other educational activities" (Švec, 1997, p. 3).

We find it necessary to explain the difference between reflection and self-reflection. These terms are often incorrectly considered identical.

Kasáčová (2005) draws upon Wright and points out the difference between reflection and self-reflection. Reflection means rational thinking and contemplating about 
one's ongoing or past activities, while self-reflection is connected with meta-cognition and aims to modify and rectify the teacher's own recognition processes in concrete educational situation with the help of monitoring, evaluation and clarification of their regulation.

An interesting opinion is offered by Smytha (1989), who considers reflection to be a preliminary stimulus for self-reflection. To build on his idea, we may say that reflection and self-reflection cannot be strictly separated from each other but rather have to be understood holistically.

The purpose of professional self-reflection is not only about getting to know yourself but also about creating a relationship towards yourself, the students and other educational staff. Thus the important thing is the so called self-concept of the teacher. The core of professional self-reflection is formed by three aspects:

1. Self-realisation, self-concept - this is a cognitive structure recorded in the consciousness that corresponds to understanding of oneself and the effort to know oneself (Výrost - Slaměník, 1997). There are two levels of self-concept in the personality psychology; a real ego (actual self-reception) and an ideal ego (desired notion of oneself; what kind of teacher one wants to be or could be). The degree of conflict between the level of the real ego and the ideal ego determines mental maturity, the mental level of personality and the ability to adapt to different situations in the educational process. Dissatisfaction with oneself or having a weak ego can often lead to uncertainty and to confusing behaviour of the teacher (Nakonečný, 1998).

2. Self-evaluation as a process, but also as the result of the self-evaluation process this aspect presents the emotional side of professional self-reflection. Self-evaluation generally means mental exponent of the emotional relationship towards oneself (Blatný - Plháková, 2003). The development of the relationship with oneself is based on 4 basic processes:

- The phenomenon of mirror "me" - other people serve as a mirror and enable us to see ourselves. A teacher's "me" is the concept of how the teacher believes he/she is evaluated by other people, students, colleagues at work;

- Social comparison - a person may use it to verify what is considered appropriate and what is unacceptable and undesirable,

- Acceptance of social roles - one assumes roles which are globally accepted and socially valued rather than those which are less accepted;

- Perception of social difference - every person (every teacher) has a need to point out his/her originality in a new environment (Gergen In Výrost - Slaměník, 1997).

3. Conduct - describes the behavioural aspect of professional self-reflection. Conduct may be understood as readiness to act in accordance with the knowledge and evaluation of oneself (Výrost - Slaměník, 1997). The teacher may find more important his/her personal success or expectations of the others; that is, how the teacher 
is perceived by other people and what advice they are providing. The former refers to a teacher with a low level of self-monitoring while the latter refers to a teacher with a high level of self-monitoring (Hupková, 2006).

The degree of self-monitoring is also important. The personality of the teacher should be autonomous and authentic.

Professional self-reflection in educational and didactic work of a teacher implies the following:

- it avoids stereotyping because the teacher strives to find methods and forms of work which may have not been used very often;

- it allows the teacher to verify these methods and forms and to compare previous results of educational work with current results acquired by means of these new, infrequently used educational means;

- by means of professional self-reflection the teacher learns to anticipate possible consequences of his/her educational influence;

- it inspires the teacher to confront his/her current "me" with the concept of an ideal teacher;

- no less important is the fact that it leads to the modernisation of education and extracurricular educational activity (Petlák, 2000).

\section{Content orientation of professional reflection}

When we talk about teachers' reflection, it is obvious that its content orientation will be based on the scope of work and on everyday activities with the students in school and school educational facilities. We will discuss 4 categories which are becoming the object of contemplation for the teacher. The teacher is looking retrospectively on individual elements constituting these categories, contemplates about achievements or failures at work and collects necessary information from students and colleagues that could form the basis for correction and innovation. These categories are:

- education and extracurricular educational activity,

- curriculum,

- ethical principles of education and extracurricular activity,

- social context of education and extracurricular educational activity (adjusted according to Hupková, 2004).

These elements shall be named and further analysed in the following text. We will draw upon the practice and requirements imposed on teachers and tutors from public and private point of view (every person creates an idea about oneself and has own targets that he/she wants to achieve). 
1. Education and extracurricular educational activity:

a) educational target - its correspondence with the abilities and knowledge of the students; developing every aspect of students' personalities while respecting their individual skills;

b) educational, didactic and diagnostic methods - variability of the use of methods; following a strict procedure for their use; their use should be compliant with educational principles and targets; combining methods with various organizational forms of education;

c) classroom climate - relations between the students; relationship between the teacher and students; knowing the boundaries in relationships (the teacher cannot be a friend to students but an authority); support of pair and group work in students;

d) pedagogical communication - its adjustment to actual knowledge of the students (understanding of terms when explaining the curriculum; minimum use of special expressions and foreign words; presenting easy to follow examples in order to comprehend new knowledge); asking the students specific and comprehensive questions during various activities; using pedagogical humour and tact;

e) subject of study - the teacher should take into account that students also have other subjects (or interest group, educational activities) on which they have to focus their efforts and educational activities. The teacher should not leave out the introductory diagnosis that will provide information not only about the abilities, knowledge and skills students have but also what are their interests, what subjects they are interested in or why they show aversion to certain subjects, etc.

2. Curriculum:

a) structure of the curriculum - logical composition of knowledge within the curriculum, differentiation of key, supplementary and expanding content of the curriculum;

b) content of the curriculum - must be in line with a specified educational target, that is to focus on the cognitive, affective and psychomotoric areas which are particularly important (understand before remember, respond before receive, manipulate before imitate, etc.), emphasise appropriate use of various thought operations (analysis, synthesis, comparison, analogy, abstraction);

3. Ethical principles of education and extracurricular activities:

a) comply with set rules for all students - the teacher makes sure that same rules apply to all students in the classroom where he/she performs didactic and educational activities (exams, gaining points for activity, punishing students for misdemeanour, dealing with learning difficulties of every student); 
b) avoid denial of students' qualities and values by underestimating and insults - the teacher shouldnot make any prejudiced judgements and opinions about his/ her students. When expressing an opinion about a student the teacher must avoid the use of pejorative and vulgar expressions. Trust between the teacher and students is very important (they should hold their discussions private);

c) assertiveness, congruence and acceptance - the teacher must know how to say no. The teacher should be able to openly and fairly express dissatisfaction or lack of time to address a specific issue. The teacher's thinking and acting must be congruent. This means accepting students and their uniqueness;

d) demonstrate satisfaction with one's own work - the teacher must demonstrate to students that he/she enjoys teaching, wants to become an expert in his/ her subject area and expand his/her professional competence. Students must understand that teaching is a job, not a diagnosis;

e) cope with stressful situations - the teacher's personal life cannot be a part of their work. Students will protest against irrational punishments and shouting (by means of intentional distraction, not listening to instructions) or they will become irresponsible towards given tasks and will not be willing to complete them.

f) constructively solve problems - private conversation during a break about a problem in the classroom or outside the classroom is more acceptable than talking to a student or lecturing him in front of the whole class. It is important to know the nature of the problem and then try to reach a consensus between the parties.

\section{Social context of education and extracurricular activities:}

a) school culture - "It is a set of ideas, attitudes and values which are generally accepted and maintained for relatively long time" (Harkabus, 2004, p. 1). The teacher should have an interest on the overall picture of the school. The teacher should be thinking about the following: evaluation of the school, application of innovative approach towards the student (principles and methods of constructivism and socio-constructivism, multicultural education, etc.).

Self-reflection is a tool that helps us to become aware of our behaviour and understand what we do and why. At the same time it also supports learning and is one of the main professional qualities. It may be said that self-reflection contributes to proper and effective acquirement of teaching skills and techniques. 


\section{Frequency of self-reflection of the secondary school teachers and their frequency of reflection of educational elements presented in partial results of the research}

In 2015, we conducted an empirical research at secondary schools in the Orava region (districts of Námestovo, Trstená, Dolný Kubín). The research sample consisted of teachers. The research was conducted among 82 teachers ( 6 young teachers, 23 independent teachers, 27 teachers with the $1^{\text {st }}$ attestation, 26 teachers with the $2^{\text {nd }}$ attestation/46 general education teachers, 36 vocational education teachers/ 17 teachers of interest groups, 12 teachers with other educational activities - classroom related classes, remedial classes). We have strived to make an even selection of the research sample, at least in the categories of individual teachers, teachers with the $1^{\text {st }}$ attestation, teachers with the $2^{\text {nd }}$ attestation/general education teachers, vocational education teachers. The number of young teachers was small (therefore evenness could not be achieved). Our sample group wasnot representative since we had no information about the basic group, i.e. about the division of teachers according to career level and type of education in the Slovak Republic. The results of the research are therefore generalised only on the research group. We used the questionnaire method and predominantly made use of a frequency scale. Its validity was ensured by precise defining of the frequency (every day, 3 times a week, once a week, once every 2 weeks and never). The respondents also had the opportunity to report another frequency, if none of the above applied to them. We compared the opinions of the teachers by means of a comparative analysis.

Primary focus has been on:

- frequency of teachers' self-reflection from the point of view of their career level and type of education,

- frequency of reflection of educational elements from the point of view of teachers' career level and the type of education,

- frequency of reflection of educational elements from the point of view of teachers' educational activity in extracurricular time.

The results of the research are included in the following tables T1, T2, T3, T4 and T5. We made use of descriptive statistics (modus, average order) and inductive statistics (Kruskal-Wallis test, Mann-Whitney test). 


\section{Table 1}

Frequency of professional self-reflection from the point of view of career level of the teachers

\begin{tabular}{|c|c|c|c|c|c|}
\hline \multirow{4}{*}{$\begin{array}{l}\text { Frequency } \\
\text { of professional } \\
\text { self-reflection }\end{array}$} & \multicolumn{4}{|c|}{ Career level of the teachers } & \multirow{2}{*}{$\begin{array}{l}\text { P-value } \\
(P \leq 0.1)\end{array}$} \\
\hline & Young & Individual & $1^{\text {st }}$ attestation & $2^{\text {nd }}$ attestation & \\
\hline & \multicolumn{4}{|c|}{ Average order } & \\
\hline & 35.33 & 46.61 & 35.94 & 44.17 & 0.264 \\
\hline
\end{tabular}

Source: Michal Novocký, 2015

Table T1 shows that there is no statistically significant difference ( $P$-value $=0.264)$ in the frequency of professional self-reflection, when it comes to teachers' career levels (mostly daily, 3 times a week). The result suggests that the respondents prepare regularly for their teaching obligations. Preparation for the lessons is one of the key self-reflective methods while it also has a taxonomic character because it employs asking various questions regarding the educational elements. These questions are:

- Are my learning objectives reasonable and well controlled? Do I communicate the content of the curriculum in a clear and understandable way?

- Do I always have material prepared for the lesson?

- Do I give the students easily understandable instructions?

- Do I give questions to the whole class? Do I use open as well as closed questions?

- Are my classes appropriate for all my students?

- Do I support the use of several learning activities?

- Do I maintain such discipline during the classes that is helpful for the students in the process of learning? etc. (Kyriacou, 2004).

The table clearly shows that the individual teachers (46.61) and the teachers with the $2^{\text {nd }}$ career level (44.17) have the highest frequency of professional self-reflection. This is a positive finding because it shows that the teachers strive to avoid routine in their jobs and that is helpful for improving students" motivation. 
Table 2

Frequency of professional self-reflection from the point of view of the type of education of the teachers

\begin{tabular}{|c|c|c|c|}
\hline \multirow{2}{*}{$\begin{array}{c}\text { Frequency } \\
\text { of professional } \\
\text { self-reflection }\end{array}$} & \multicolumn{2}{|c|}{ Type of education of the teachers } & $\begin{array}{c}\text { P-value } \\
(\mathrm{P} \leq 0.1)\end{array}$ \\
\cline { 2 - 4 } & General & Vocational & \\
\cline { 2 - 4 } & \multicolumn{2}{|c|}{ Average order } & \\
\cline { 2 - 4 } & 42.42 & 40.32 & 0.676 \\
\hline
\end{tabular}

Source: Michal Novocký, 2015

The data from table $\mathrm{T} 2$ indicate that there is no connection between the type of education of the teachers and their frequency of professional self-reflection ( $P$-value $=0.676$ ). However, the average order indicates that general education teachers have a higher level of professional self-reflection when compared to vocational education teachers. Regardless of the nature of the study subject, the respondents replied that they engage in professional self-reflection mostly every day and 3 times a week. Most of the teachers prepare for their classes beforehand. However, there may be some differences in the frequency of reflection of the educational elements.

It must be noted that a reflective professional always has a range of questions prepared about himself, his job and the students. By engaging professional self-reflection the teacher confirms the level of development of his/her professional competences and eliminates the danger that these competences will be decimated by a stable routine that limits improvement.

Table 3

Frequency of reflection of educational elements from the point of view of the type education of the teachers

\begin{tabular}{|l|c|c|c|}
\hline \multirow{2}{*}{ Elements of education } & \multicolumn{2}{|c|}{ Type of education of the teachers } & $\begin{array}{c}\text { P-value } \\
(\mathrm{P} \leq \mathbf{0 . 1})\end{array}$ \\
\cline { 2 - 4 } & General & Vocational & \\
\cline { 2 - 4 } & \multicolumn{2}{|c|}{ Average order } & \\
\hline Use of activating methods & 37.20 & 47.00 & 0.054 \\
\hline Comprehensibility of the questions & 46.92 & 34.57 & 0.015 \\
\hline
\end{tabular}

Source: Michal Novocký, 2015

It is clear from the data in table T3 that in connection with the type of education of the teachers there are some statistically significant differences in the reflection of compli- 
ance with a detailed procedure of using activating methods and asking the students comprehensible questions. The first element is highly reflected (mostly 3 times a week) by vocational education teachers (47.00). The reason may be that the teachers of vocational subjects can make use of several activating methods, such as the role-playing method, situational method, case method and didactic games.

However, vocational education teachers pay less attention to asking students comprehensible questions (34.57). As has been pointed out in the previous table, we believe that if students have no problems understanding the questions asked and responding to them, then the teachers do not find it necessary to contemplate about them more frequently. On the other hand, we think that when activating methods are used care must be taken as to what types of questions are addressed to students and if these are comprehensible for all of them. Just in case, the teacher should have some alternative questions prepared.

Table 4

Frequency of reflection of educational elements from the point of view of the career level of the teachers

\begin{tabular}{|c|c|c|c|c|c|}
\hline \multirow{3}{*}{ Elements of education } & \multicolumn{4}{|c|}{ Teachers' career level } & \multirow{3}{*}{$\begin{array}{c}P \text {-value } \\
(P \leq 0.1)\end{array}$} \\
\hline & Young & Individual & $1^{\text {st }}$ attestation & $2^{\text {nd }}$ attestation & \\
\hline & \multicolumn{4}{|c|}{ Average order } & \\
\hline $\begin{array}{l}\text { Ensuring that set targets has } \\
\text { been met }\end{array}$ & 23.17 & 51.63 & 40.02 & 38.31 & 0.023 \\
\hline $\begin{array}{l}\text { Knowledge of the students' } \\
\text { learning styles }\end{array}$ & 70.17 & 41.26 & 40.76 & 35.87 & 0.010 \\
\hline Use of activating methods & 41.17 & 50.98 & 33.50 & 41.50 & 0.063 \\
\hline Satisfaction with work & 29.33 & 49.54 & 35.98 & 42.92 & 0.099 \\
\hline $\begin{array}{l}\text { Comprehensibility } \\
\text { of the questions }\end{array}$ & 22.08 & 51.24 & 37.44 & 41.58 & 0.021 \\
\hline
\end{tabular}

Source: Michal Novocký, 2015

Table T4 presents a statistically significant difference in the frequency of reflection of educational elements in the educational process in relation to the teachers' career level. The highest frequency of reflection (mostly 3 times a week) was recorded in the group of the independent teachers (51.63). In our opinion, this result is due to their length of practice. It may be seen that more regular reflection in terms of ensuring that set educational targets have been met has a great effect on the effectiveness of educational process and learning results of the students.

Young teachers strongly reflect (mostly 3 times a week) their knowledge of the students' learning styles from the point of view of the used didactic methods (70.17). 
This is one of the key capabilities teachers should be able to manifest in their work. The independent teachers and teachers with the $1^{\text {st }}$ attestation do not underestimate this fact either (their frequency of reflection is 3 times a week and once a week).

The above suggests that the respondents are familiar with the professional standard, and the knowledge of students' learning styles lets them chose more adequately what the other education methods and organizational forms to exploit.

Reflection of the compliance with exact procedure of the use of activating methods (mostly 3 times a week) in teaching was one of the priorities for the independent teachers (50.98). Again, the influential factor is the length of practice. We think that a teacher who uses activating methods is aware of the fact that an exact procedure of their implementation ensures stronger motivation of the students to be active while their use may also help develop students' higher thinking operations, such as analysis, synthesis, abstraction, etc.

Every teacher must show his/her satisfaction with his/her job as it may ultimately have a motivational effect on students. The independent teachers (49.54) and the teachers with the $2^{\text {nd }}$ attestation (42.92) consider reflection of this element to be crucial for their job (mostly 3 times a week). The young teachers do, however, underestimate this element (29.33). The reason may be that they need some time to adapt to their new jobs, and therefore they initially pay attention to other elements which may affect the level of satisfaction with their job.

Reflection of addressing students comprehensible with questions is underestimated by the young teachers (22.08) as opposed to the independent teachers (51.24). The independent teachers reflect this element mostly 3 times a week. This may be affected by the length of practice but also by the targets and educational strategies of the young teachers which are only in their initial, forming phase. On the other hand, we must note that there are many factors in the educational process that guide the reflection of the teachers to the important elements. We think that if students understand the questions asked by teachers and their answers are correct, then teachers do not feel the need to contemplate about them. 
Table 5

Frequency of reflection of educational elements from the point of view of extracurricular educational activities of the teachers

\begin{tabular}{|l|c|c|c|}
\hline \multirow{2}{*}{ Elements of education } & \multicolumn{2}{|c|}{ Extracurricular educational activity } & $\begin{array}{r}\text { P-value } \\
\text { (P } \leq 0.1)\end{array}$ \\
\cline { 2 - 4 } & Interest groups & $\begin{array}{c}\text { Classroom related classes/ } \\
\text { remedial classes }\end{array}$ & \\
\cline { 2 - 4 } & \multicolumn{2}{|c|}{ Average order } & $\underline{0.119}$ \\
\hline $\begin{array}{l}\text { Knowledge of the students' } \\
\text { learning styles }\end{array}$ & 12.94 & 17.92 & 0.055 \\
\hline $\begin{array}{l}\text { Students' respectful } \\
\text { treatment of each other }\end{array}$ & 17.47 & 11.50 & 0.039 \\
\hline Use of activating methods & 17.59 & 11.33 & \\
\hline
\end{tabular}

Source: Michal Novocký, 2015

Table T5 indicates a statistically significant difference in the frequency of reflection of knowing students' learning styles from the point of view of used didactic methods in connection with the educational activity of the teachers. Those teachers who lead classroom-related classes use this time to expand the content of the curriculum or to strengthen it. They may also use the classroom-related classes to check students' prerequisites and levels of knowledge (personality tests, tests of skills, etc.).

Students' respectful treatment of each other from the point of view of used educational methods is reflected more frequently (mostly 3 times a week) by the teachers of interest groups (17.47). It may be assumed that the teachers of interest groups meet new students each year and it is desirable that they pay attention to their discipline and create opportunities for them to develop their interests and shape relationships.

Reflection of the compliance with an exact procedure of the use of activating methods is the domain of the teachers of interest groups (mostly 3 times a week). Interest groups provide space for the performance of several practical tasks and activating methods, and we think that the respondents are aware of that. The underlined P-value was crucial for the research (we assume that statistical significance could be demonstrated with a greater number of the respondents).

\section{Conclusion}

Conclusions cannot be considered generally valid, since our sample group was not representative. Despite that, we shall specify some recommendations for practice: 
- Young teachers should think more frequently (at least 3-times a week) about ensuring that set educational targets are met; otherwise they cannot be sure that the education is effective, and also about addressing the students with comprehensible questions as it can make the work with them much easier;

- Reflection of the knowledge of the students' learning styles from the point of view of used didactic methods should be equally dominant for teachers with the $2^{\text {nd }}$ attestation (at least 3 times a week) as it is for lower career levels.

Professional self-reflection is an inseparable part of educational work of the teachers. It is a tool that allows further personal and professional growth (Kouteková, 2006). Every teacher should be aware of their thoughts, feelings and reasons behind their actions in a specific teaching situation that would help them achieve optimal working results.

\section{References}

Blatný, M. \& Plháková, A. (2003). Temperament, inteligence, sebepojetí: Nové pohledy na tradiční témata psychologického výzkumu. Brno: Psychologický ústav AV ČR.

Harkabus, Š. (2004). "Tlačení minulostou" alebo "t’ahaní budúcnostou" o potrebe zmeny kultúry slovenskej školy. Pedagogické rozhlady, 13, (1): 1.

Hupková, M. (2004). Sebareflexia vo výchovno-vzdelávacej práci učitela. In Sebareflexia a kompetencie $v$ práci učitel'a. Bratislava: IRIS.

Hupková, M. (2006). Profesijná sebareflexia učitelov. Nitra: PF UKF.

Kasáčová, B. (2005). Reflexívna výučba a reflexia v učitel'skej príprave. Banská Bystrica: PF UMB.

Kouteková, M. (2006). Osobnost'vychovávatel’a v systéme výchovy mimo vyučovania. 2. vyd. Banská Bystrica: PF UMB.

Kyriacou, Ch. (2004). Kličcové dovednosti učitele. Praha: Portál.

Nakonečný, M. (1998). Psychologie osobnosti. Praha: ACADEMIA.

Novocký, M. (2015). Profesijná sebareflexia a profesijné kompetencie vo výchovno-vzdelávacej práci učitela strednej školy (Rigorózna práca). Banská Bystrica: PF UMB.

Petlák, E. (2000). Pedagogicko-didaktická práca učitela. Bratislava: IRIS.

Smyth, J. (1989). Developing and Sustaining Critical Reflecion in Teacher Education. Journal od Teacher Education. 40, (2): 4-6.

Švec, V. (1997). Sebareflexe jako nástroj profesionálního (sebe)rozvíjení začínajícich učitelů. Pedagogická orientace. (3): 3-9.

Výrost, J. \& Slaměník, I. (1997). Sociální psychologie - Sociálna psychológia. Praha: ISV.

\section{Contact:}

Mgr. Michal Novocký

Department of Pedagogy, Faculty of Education, Matej Bel University,

Ružová 13, 97411 Banská Bystrica, Slovak Republic

E-mail: michal.novocky@umb.sk 